\title{
One Integrated Service Quality Doors at Meureudu State Court
}

\author{
Mimin Suriadi ${ }^{1}$, Rozaili $^{2}$, Zulfikar $^{3}$ \\ ${ }^{1,2}$ Sekolah Tinggi Ilmu Manajemen Indonesia \\ ${ }^{3}$ Universitas Jabal Ghafur, Indonesia \\ miminsuryadi@gmail.com,zulfikar@unigha.ac.id,rozaili@unigha.ac.id
}

\begin{abstract}
One door integrated service policy is a new idea in service to the community. Integrated steps in this service are system changes in the implementation of activities to facilitate the Meureudu district court in serving the community, this policy requires processes and innovations for service providers, one door integrated service guidance and direction full of today's technological challenges., the role in the system that is carried out cannot be separated from the challenges of circumstances that can cause deviations in an activity. The authors use a descriptive qualitative approach which is basically an attempt to reveal a problem or situation or event as it should be so as to provide an objective picture of the actual state of the object under study. Research results and discussion, In improving services to the needs of the community, the Meureudu district court has facilitated and guided its employees in providing services, a simple, fast and precise service process requires the ability and creativity of employees and for the implementation of these activities this greatly affects the leadership role that manages the wheels of activity in the court. The success of the Meureudu District Court by obtaining a B rating means that demands for excellent service to the community are the first priority. The obstacle faced by the Meureudu District Court is that they do not have their own building and they are still using the Pidie Jaya Regency government building which has been granted the right to use this greeting. fast and precise requires the ability and creativity of employees and for the implementation of this activity is very influential in the leadership role that manages the wheels of activity in the court.
\end{abstract}

Keywords

quality, one stop senvice

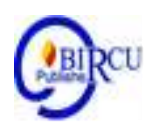

\section{Introduction}

One stop service policy (PTSP)operating these policies is an intrinsically not new tool. Integrated approaches are nothing but a systems approach, but in their implementation there are connecting routes that are independent of the policy actors. This situation can cause irregularities in the implementation of a component being implemented. Service is an activity or a series of invisible activities that occur as a result of the relationship between customers and employees provided by the company by providing services intended to solve customer problems.

Meanwhile, according to Freed Luthansn's opinion (2016: 54) Service is a procedure of fulfilling the needs of passing through other people's activities that involve all problems addressed by others to solve problems. In order to encourage the improvement of the quality of court services in Indonesia through bureaucratic reform activities, the Supreme Court has established 23 court organization units to be proposed to be awarded the Corruption Free Area (WBK) and the Clean Serving Bureaucratic Area (WBBM). 
Currently, these organizational units are taking part in a sampling conducted by the Supreme Court Bureaucratic Reform Team and some others are being carried out together with the Ministry of State Apparatus Empowerment and Bureaucratic Reform Team (Kemenpan RB).

Related to this, the Secretary of the Supreme Court, AS Pudjoharsoyo, SH, M. Hum as the person in charge of bureaucratic reform at the Supreme Court reminded the basic and substantive meaning of bureaucratic reform. "The meaning of bureaucratic reform is maximum service to the public that is free from corruption and extortion. What was conveyed by Pudjoharsoyo has relevance to the target of the third wave of bureaucratic reform in 20152019. In this period, bureaucratic reform was aimed at at least three main targets, namely a clean and accountable bureaucracy, an effective and efficient bureaucracy, and a bureaucracy that had quality public services. The definition of One Stop Integrated Service (PTSP) is, Legal Basis, Types of PTSP, and Constraints in Its Implementation. Licensing services in setting up a business in Indonesia continue to be improved and made easier. The government has made efforts to simplify services both licensing and non-licensing, namely by implementing the One Stop Integrated Service system or abbreviated as PTSP. What is meant by one-stop integrated service (PTSP) or in English is called the one-stop integrated service.

One-stop integrated service (PTSP) is not a new policy in bureaucratic management. The establishment of PTSP in the regions is included in the framework of getting closer and improving services to the community and shortening the service process in order to realize fast, easy, cheap, transparent, certainty and affordable services. With the existence of the PTSP, licensing applicants no longer need to manage various letters and documents at different offices with different office locations.

Service quality must start from customer needs which end in customer perception. This means that the image of service quality is not the perception of service providers but of customers. It is the customers who consume and enjoy the services of an agency, so they are the ones who should be the quality of service. Customer perception of service quality is a comprehensive assessment of service excellence. According to Supranto (2011: 227), "Service quality is an activity offered by one party to another party and is basically intangible and does not result in ownership of a production process and is also not associated with a physical product".

From the above definition, it can be interpreted that service quality is centered on efforts to fulfill customer needs and desires and the accuracy of their delivery to balance customer expectations. Service quality is the level of excellence expected and control over that level of excellence is to fulfill customer desires. So if the service received or felt is as expected, then the service quality is perceived as good and satisfying. If the service received is lower than expected, the service quality is perceived as bad.

In addition to conveying the substantive meaning of bureaucratic reform, Pudjoharsoyo also conveyed four important messages to all courts, especially those currently following a sampling of the implementation of bureaucratic reform. The four important messages are as follows:

1. So that all judicial officials are committed to unite in providing services to people who seek justice without strings attached.

2. So that all court officials carry out the agreed Standard Operating Procedure (SOP) and follow correct service procedures and maximize service in a polite and friendly manner.

3. So that all court officials realize their seriousness in implementing the application of the Case Tracking Information System (SIPP), One Stop Services (PTSP), electronic courts 
(e-court) and other applications as superior courts in public services to realize a simple, fast and low cost. And

4. To maintain the spirit of bureaucratic reform, a court that has been accredited as quality assurance does not mean that it must be completely new and classy, but must be more of a joint commitment as judicial officials in providing maximum and soothing services to the community so that people who seek justice feel protected when in court.

\section{Review of Literatures}

\subsection{Human Resources}

In general, the definition of human resources has two parts, namely: macro and micro human resources, while the definition of macro resources is the number of productive age population in a country, while the definition of micro resources is more part of individuals who work in an agency.

Meanwhile, the definition of human resources according to Malayu Hasibuan (2012: 3) human resources is an integrated ability of the thinking power and physical power of an individual, the ability of human resources cannot be seen from one side only, but must cover the whole mind and also physical powerMeanwhile, according to Nawawi in Gaol (2014: 44) human resources are people who work and function as organizational assets / companies that can be counted in number, and human resources are the potential that drives the organization.

Human resources are skills and human potential as the main element in any activity or work carried out based on their abilities. Human resource development is seen as improving the quality of ability through training and education programs, developing human resources on developmental practice and requiring collaboration with human resource management programs to achieve the desired results. The benefits of human resource development are very important because of the demands of work due to technological advances and increasingly intense competition between individuals.

According to Adiwijaya and Ningrum (2019) human development is an effort to improve human capabilities, especially through improving the level of health and education, so as to make people become healthier and more productive so that it is possible to reach opportunities available to each of them.

The program is a statement that contains the conclusions of several interdependent and interrelated expectations or goals to achieve the same goal. Usually a program includes all activities that fall under the same administrative unit, or objectives that are interdependent and complementary, all of which must be carried out simultaneously or sequentially.

According to Harjanto (2010: 12), design is related to determining what to do. Design / planning is a description of several activities, who is responsible for carrying it out and supporting factors in the form of funds and time, the clearer the work is because there are implementation instructions and tools that make it easier to carry it out, the more directed a job is because there are targets that become targets achievement as well as a barometer of achievement and the percentage of achievement of activities within a certain time. Planning can be a determinant of success and can be used as material for analysis of the truth and performance of a person in order to know the accuracy of a person and group in working.

A process of systematically preparing activities carried out to achieve certain goals. A way how to achieve the goal as best as possible (maximum) with existing resources so that it is more efficient and effective. Determination of goals to be achieved or to be done, how, when and by whom. Planning plays an important role in the scope of an activity because it determines and simultaneously gives direction to the goals to be achieved. With careful 
planning, a job will not be messy and unfocused. Careful and well-structured planning will have an influence on the achievement of goals.

Work program can be interpreted as an organizational activity plan made for a certain period of time that has been agreed upon by the organization's management. The work program in the youth organization is the obligation of the management which will later be carried out by the organization within a predetermined period of time. According to Husein Umar (2013: 34) "Work Program is an activity or process of making plans that the company will use in order to achieve its goals.

\subsection{One Stop Services}

Service is serving activities whose results are aimed at the desires of others, both individuals and groups and society. Based on the Decree of the Minister of State for the State Apparatus Number. 63 of 2003, service is all forms of service activities carried out by government agencies at the central, regional and in the environment of state or regional owned enterprises in the form of goods and services in the design of fulfilling the interests of the community and in the design of implementing statutory provisions.

Service is an activity or a series of invisible activities that occur as a result of the relationship between customers and employees provided by the company by providing services intended to solve customer problems. Meanwhile, according to Freed Luthansn's opinion (2016: 54) Service is a procedure of fulfilling the needs of passing through other people's activities that involve all problems addressed by others to solve problems.

Service innovation is the key to change conducted by companies to improve competitive advantage by accelerating the service process through innovation in new service systems that combine with technological i.e integrate retail processes and digital services elements, because digital innovation a framework for diagnosing service innovation (Kusumadewi and Karyono, 2019)

\section{a. Elements Affecting Service}

The following are some of the elements that affect service, including the following:

1. Direct Evidence: Direct evidence is actual evidence of the attention and interest the service facilitator provides to customers.

2. Reliability: Reliability is the expertise of a company to serve services in proportion to what has been determined in a timely manner.

3. Responsiveness: Responsiveness is the expertise of the company which is performed directly by employees to serve services skillfully and responsively.

4. Guarantee: Guarantee is the expertise and skills to build trust and confidence in customers in serving the services offered.

5. Empathy: Empathy is a company's expertise that is carried out directly by employees to share care for individual customers.

\section{b. Function and Service Purpose}

With the distribution of service capacity to customers, it must be useful to increasingly share maximum satisfaction with customers, because in distributing a servant must be done according to the role of the service. The general objective is to provide good service capacity so that customers expect satisfaction and will have a positive effect on the company. 


\subsection{Service Quality}

Service quality must start from customer needs which end in customer perception. This means that the image of service quality is not the perception of service providers but of customers. It is the customers who consume and enjoy the services of an agency, so they are the ones who should be the quality of service. Customer perception of service quality is a comprehensive assessment of service excellence. According to Supranto (2011: 227), "Service quality is an activity offered by one party to another party and is basically intangible and does not result in ownership of a production process and is also not associated with a physical product".

From the above definition, it can be interpreted that service quality is centered on efforts to fulfill customer needs and desires and the accuracy of their delivery to balance customer expectations. Service quality is the level of excellence expected and control over that level of excellence is to fulfill customer desires. So if the service received or felt is as expected, then the service quality is perceived as good and satisfying. If the service received is lower than expected, the service quality is perceived as bad.

\subsection{Forms of Service}

The government is the party that provides services to the community. As for the implementation of this service consists of several forms. According to Moenir (2010: 190), the form of service consists of:

Oral services Oral services are carried out by officers in the field of public relations, in the field of information services and in other fields whose job is to provide explanations or information to anyone who needs them.

Service in the form of writing This is a type of service by providing an explanation through writing in the management of community problems. Services in this form of writing are of two types, namely:

1. Services in the form of instructions, information and the like are addressed to interested people to make it easier for them to deal with institutions or institutions,

2. Services in the form of written reactions to requests, reports, complaints, giving / submission, notifications and so on.

Service in the form of an action in daily reality, this type of service is not spared from oral service, so between action service and verbal service often combine. This is because oral relationships are mostly carried out in service relationships in general. Only the emphasis lies in the action itself which is awaited by the person concerned. So the main objective concerned is to get service in the form of an act or the result of an act, not just an explanation and verbal ability. Here the speed factor in service is everyone's dream, accompanied by adequate quality results.

\subsection{Principles of Service}

To be able to provide satisfactory service to service users, service providers must meet the following service principles (Ratminto 2015: 19)

1. Transparency: Open, easy and accessible to all parties in need and provided adequately and easily understood.

2. Accountability: Can be accounted for in accordance with the provisions of laws and regulations.

3. Conditional: In accordance with the conditions and capabilities of service providers and recipients by sticking to the principles of efficiency and effectiveness.

4. Participative: Encouraging community participation in the delivery of public services by taking into account the aspirations, needs and expectations of the community. 
5. Equality of Rights: Non-discriminatory in the sense of not discriminating against ethnicity, race, religion, class, gender and economic status.

6. Balance of rights and obligations: Providers and recipients of public services must fulfill the rights and obligations of each party.

Based on the Decree of the Minister for Administrative Reform Number 63 of 2003, it is explained that in providing services, several principles must be fulfilled, namely:

1. Simplicity, service procedures / procedures are carried out easily, quickly, without complicated, easy to understand and easy to implement

2. Clarity includes several things, among others: a. Technical and administrative requirements for public services, b. The work unit or an authorized official who is responsible for providing services and resolving complaints / problems / disputes in the implementation of public services, c. Details of service fees and payment procedures

3. Certainty of time. The implementation of public services can be completed within a predetermined time

4. Accuracy. Public service products are received correctly, correctly and legally

5. Sense of secure. Public service processes and products provide a sense of security and legal certainty

6. Responsible. Leaders of public service providers or appointed officials are responsible for providing services and resolving issues or problems in the implementation of public services.

7. Completeness of facilities and infrastructure. The availability of work facilities and infrastructure, work equipment and other adequate support, including the provision of telecommunications and information technology facilities

8. Ease of access. Adequate and easy to reach place and location as well as work infrastructure and can take advantage of telematic technology

9. Discipline, courtesy and friendliness. Service providers must be disciplined, polite, and polite, friendly and provide sincere service

10. Comfort. The service environment must be orderly, provided a waiting room that is comfortable, clean, tidy, a beautiful, healthy environment and equipped with service support facilities, such as parking, toilets, places of worship, and others.

The definition of One Stop Integrated Service (PTSP) is, Legal Basis, Types of PTSP, and Constraints in Its Implementation.Licensing services in establishing a business in Indonesia continue to be improved and made easier. The government has made efforts to simplify services both licensing and non-licensing, namely by implementing the One Stop Integrated Service system or abbreviated as PTSP. What is meant by one-stop integrated service (PTSP) or in English it is called the one-stop integrated service.

One-stop integrated service (PTSP) is not a new policy in bureaucratic management. The establishment of PTSP in the regions is included in the framework of getting closer and improving services to the community and shortening the service process in order to realize fast, easy, cheap, transparent, certainty and affordable services. With the existence of the PTSP, licensing applicants no longer need to manage various letters and documents at different offices with different office locations. 


\section{Research Methods}

In this study the authors use a descriptive qualitative approach limited to trying to reveal a problem or situation or event as it is so that it is to reveal facts and provide an objective picture of the actual situation of the object under study, then Sugiyono (2010:11) argues that qualitative research aims to reveal qualitative information so that it emphasizes process and meaning problems by describing a problem.

\subsection{Research Sites}

The research location is a place or area where the research will be carried out. The place of research to be carried out by the author is at the Meureudu District Court Pidie Jaya District.

\subsection{Population and Sample Research}

In qualitative research, the main research informants are the researchers themselves. Because according to Nasution in Sugiyono (2010: 25) researchers are sensitive tools and can react to all stimuli from the environment which he must estimate to be meaningful or not for research.

Guba and Lincoln in Moleong (2014: 168) humans as a research instrument include general characteristics, expected qualities, and the possibility of human improvement as an instrument. Moleong (2014: 169) General characteristics as an instrument include a responsive aspect, can adapt to knowledge, process and summarize, and take advantage of opportunities to seek common responses. In addition, researchers as an instrument can immediately analyze the data obtained.

So in this case the research sample is 1 Deputy Chief Justice, 1 secretary, 1 Head of Subdivision Planning, information and reporting technology, 1 head of subdivision of personnel, organization and management, 4 employees,

\subsection{Technique of Data Collection}

Data collection techniques are the most important step in research, because the main purpose of research is to get data, without knowing data collection techniques, researchers will not get data that meets the data standards set. Opinion Sugiyono (2014: 308)

Explained that when viewed from the data source, data collection can use primary and secondary sources. Primary sources are data sources that directly provide data to data collectors and secondary sources are indirect sources that provide data to data collectors. Furthermore, when viewed in terms of methods or techniques of data collection, data collection techniques can be done by observation (observation), interview (interview). Questionnaire (questionnaire), documentation and a combination of the four

Based on the required data sources, the data collection method in this study was carried out through:

1. Direct observation, is a process of daily activities using the five senses and the ear as the main tools, so that first hand obtaining information and data by observing people and places at the time of the research, while observing, researchers participate in doing what the data sources do and feel the joy and sorrow. Then the data obtained will be more complete, sharp and to know the level of meaning of each visible behavior. In this case the researcher will be involved with the activities carried out by the population and civil registration services in carrying out their activities. This observation is done by using a camera or other mechanical device that can assist in research. 
2. Interview, is a data collection technique to find problems that must be researched. Interview (interview) can be viewed as a method of collecting data by way of one-sided answer, which is done systematically and based on research objectives. Interviews were conducted with structured interviews to explore as much information as possible from the instrument. The selection of respondents was carried out by poor positive sampling, namely sampling determined by the author himself in accordance with the problems studied in data collection through interviews carried out by using a tape recorder or other mechanical device.

3. Documentation Studies, According to Sugiyono, (2014: 326) documents are records of past events, can be in the form of writings, images or monumental works of a person or an event. Document study is a complement to the use of observation and interview methods in qualitative research.

\subsection{Technique of Data analysis}

Miles and Huberman in Sugiyono, (2010: 338) suggest that in qualitative research, data analysis is carried out since the beginning of the study and during the research process. Data is obtained, then collected to be processed systematically, starting from interviews, observation, editing, classifying, reducing, then data presentation activities and concluding data. According to Sugiyono (2014: 333)

Who expressed his opinion that data analysis is the process of searching and systematically arranging data obtained from interviews, field notes and documentation by organizing data into categories, describing them into units, compiling patterns, choosing which ones are important and which will be studied and making conclusion so that it is easily understood by oneself and others.

Analysis is the preparation of data that has been processed to get a conclusion, in analyzing the data the author uses a qualitative analysis method, namely an analysis that describes conditions and events as a whole with descriptions carried out by researchers based on legislation, expert views, including the experience of researchers and the author's explanation in the field.

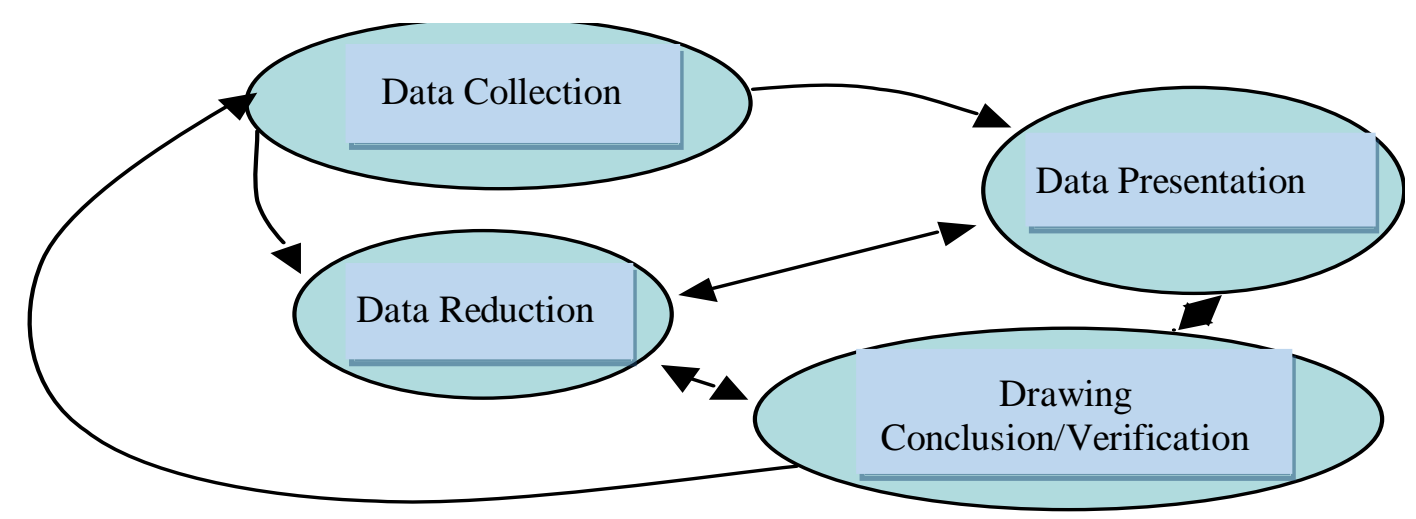

Source: Qualitative Data Analysis

Figure 1. Interactive Analysis from Miles and Huberman in Sugiyono (2010: 338)

As for the picture above, this interactive analysis process can be presented in the form of images as Miles and Huberman in Sugiyono (2010: 338) which are classified into 3 (three) components of analysis, namely reduction, data presentation, drawing conclusions can be presented as expected by the researchers themselves . 
The analysis process in this study was carried out in four stages, namely:

1. Data collection, data obtained from interviews, observations and documentation are recorded in field notes which consist of two parts, namely descriptive and reflective. Descriptive notes are natural notes, notes about what the researcher sees, hears, witnesses and experiences without the opinion and interpretation of the researcher on the phenomenon being experienced. Reflective notes are notes that contain the researchers' impressions, comments, opinions and interpretations regarding the findings found and are material for the data collection plan for the next stage.

2. Data reduction, after the data is collected, data reduction is then made, in order to select relevant and meaningful data, focusing data that leads to problem solving, discovery, and meaning or to answer the researcher's questions. Then simplify and organize systematically and describe important things about the findings and their meaning. In the data reduction process, only data findings or findings relating to research problems are reduced. Meanwhile, data not related to research problems were discarded. In other words, data reduction is used for analysis that sharpens, classifies, directs and removes what is not important, and organizes data so that it makes it easier for researchers to draw conclusions.

3. Data presentation, data presentation can be in the form of writing or words, pictures, graphs and tables. The purpose of presenting data is to combine information so that it can describe what happened. In this case, so that researchers do not have difficulty in mastering information either as a whole or in certain parts of the research results, the researcher must create a narrative, matrix or graphic to facilitate mastery of the information or data. Thus, researchers can still master the data and not drown in information conclusions that can be boring. This is done because the scattered and poorly structured data can influence the researcher to act carelessly and draw impartial, fragmented and unfounded conclusions.

4. Withdrawal of conclusions, conclusions are drawn during the research process as is the process of data reduction, after sufficient data has been collected then a temporary conclusion is drawn and after the data is completely complete, a final conclusion is drawn.

\section{Results and Discussions}

\subsection{Results}

The times have made people's needs increase, of course judicial administrators need to adjust themselves in order to provide the best service to the community. Therefore, the implementation of public services is one of the efforts to improve the quality of courts.

Innovative activities carried out at the Meureudu District Court, namely, providing a parking space, creating a waiting room for court visitors, which initially did not have a waiting room. Besides that, the one-stop integrated service officer must have the qualifications to understand the service standards of service procedures and court procedures for every case that is the authority of the Meureudu district court.

The one-stop integrated service program is the service provided by the Meureudu district court in a structured manner in a single unified process starting from the stages of application, complaint, case registration, payment and purchase of court fee down-payments to delivery or collection of court products through one-stop services. One-stop integrated services are operated with the aim of:

1. Realizing simple, fast and precise court servants

2. Providing services that are easy, sure, measurable and free from corruption.

3. Maintain the independence and impartiality of the court apparatus 
This was confirmed by the Secretary of the Meureudu Court, stating that: the services provided to the community are in accordance with one-stop integrated services (PTSP). This can be seen from the success so far including requests for information; case registration, payment of fees; delivery of court products; and filing complaints / complaints.

In accordance with what is said by the employees who carry out activities that serve the community, we are employees who serve the community with the obligations given by the leadership in optimizing services, always provided under any circumstances

In the one-stop integrated service (PTSP) the Meureudu district court has implemented integrated services well, as said by the Deputy Chairperson, the Meureudu District Court has implemented properly according to the one-stop integrated service (PTSP) standard set by the government with correct governance .

In 2019 the Meureudu District Court asked each work unit under it to independently assess the One Stop Integrated Service of each work unit so that the appellate court could measure the extent to which the PTSP implementation was successful and the obstacles faced in implementing one-stop integrated services (PTSP) ).

Initially court services were initiated from one room to another, one table to another or the table system I, II and III, this condition has been deemed ineffective and efficient in its application, so that a new breakthrough has emerged called the One Stop Integrated Service. (PTSP). The Meureudu District Court has implemented this system.

The condition of one-stop integrated service (PTSP) The current court is still able to run well even though there is a shortage of personnel in the first service sector considering that those assigned to the main service are honorariums but the Meureudu district court tries to make the public no longer feel confused while in the court office because at the main door they have been welcomed / received and directed where and what is the purpose of their coming to the Court. One-stop integrated service (PTSP) The court still needs an arrangement / improvement in such a way, in order to provide even more optimal service, creating a comfortable, calm and cool atmosphere, both by court users and court officials themselves.

\subsection{Discussion}

\section{How are the Integrated Service Standards at the Meureudu District Court?}

The times have also changed the needs of society, of course judicial administrators need to adjust themselves in order to provide the best for the community. Therefore, organizing an innovation competition in terms of public services is one of the efforts to improve the quality of courts.

Innovation is a process and / or the result of developing the use or mobilization of knowledge, skills and experiences to create or improve new products, processes and / or systems that provide significant value. In an era that is all digital with the development of information technology, public servants are always appointed to be more creative and innovative in providing maximum public services.

In order to improve services to information needs and accelerate cases for justice seekers at the Meureudu District Court and improve performance for Meureudu District Court employees, there is a need for innovation and development of several facilities to meet these needs, one of the innovations of the Meureudu District Court in providing better public services. Prime for justice seekers is to provide comfortable facilities for justice seekers. Innovative activities carried out at the Meureudu District Court, namely, making parks, making parking lots, making green parks open, making waiting rooms for court visitors, which initially did not have a waiting room at the Meureudu District Court.

In addition, PTSP service officers must have qualifications to understand Court Service Standards, administrative procedures and court proceedings for each type of case that is the 
authority of the District Court, understand court profiles such as organizational and trial structure, regulations, decisions and policies issued by the Supreme Court of the Republic. Indonesia and the Directorate General of General Courts, have the ability to operate computers and have good communication skills, are polite and friendly, and have a neat appearance.

Perpreparations for these activities have started since early 2019 by preparing all relevant documents, including the decree for the formation of the TAPM Team, quality manuals, SOPs, other control documents, shame culture, 3S culture and 5R culture as well as improving the public service system with a counter system and One Stop Services (PTSP). From the statement of the chairman of the Meureudu District Court, it was stated:

PerPreparation for accreditation has started at the first time the office of the Banda Aceh High Court Accreditation Assessment Team has conducted an assessment and the results are announced in the Submission Ceremony of the Quality Assurance Accreditation Certificate for General Courts on 18 September 2019 at the Secretariat Building of the Supreme Court of the Republic of Indonesia and based on the Certificate received Number TAPM 027 / QMR / Certificate.1 / 09/2019 Meureudu District Court Accredited "B".

The success of the Class II Meureudu District Court in achieving the title of "B" is proof that the Class II Meureudu District Court has provided excellent service to justice seekers. This proves that there has been an increase in the quality of services provided by the Meureudu Class II District Court. It is hoped that the Class II Meureudu District Court family will be able to increase the accreditation predicate "B" to "A" (Excellent) in 2020

The one-stop integrated service program is an integrated judicial administration service in one unified process starting from the stages of requesting information, complaints, registering cases, paying and returning court fees, to submitting / taking court products through one-stop services. PTSP is formed and operationalized with the aim of:

1) Realizing a simple, fast and light-aged judicial process.

2) Providing easy, definite, measurable and corruption-free administrative services to service users;

3) Maintain the independence and impartiality of the court apparatus.

This was confirmed by the Secretary of the Meureudu Court, stating that: the services provided to the community are in accordance with one-stop integrated services (PTSP). This can be seen from the success so far includes requests for information; case registration, payment of fees; delivery of court products; and filing complaints / complaints.

In order to know the implementation of one-stop integrated service (PTSP) in the Meuruedu State judiciary, it has implemented and implemented services through one-stop integrated services (PTSP) properly. As the Deputy Chairperson said, the Meureudu District Court has implemented properly according to the one-stop integrated service (PTSP) standard set by the government with correct governance.

In 2019 the Meureudu District Court asked each work unit under it to independently assess the One Stop Integrated Service of each work unit so that the appellate court could measure the extent to which the PTSP implementation was successful and the obstacles faced in implementing one-stop integrated services (PTSP) ).

As for the obstacle most felt by the Meureudu District Court is the limitations of the building and other facilities that sometimes serve the public but services are still carried out to make it easier for the public to complain. In accordance with what is said by the employees who carry out activities that serve the community, we say that employees who serve the community with the obligations given by the leadership in optimizing services are always provided under any circumstances, 
Initially court services were initiated from one room to another, one table to another or the table system I, II and III, this condition has been deemed ineffective and efficient in its application, so that a new breakthrough has emerged called the One Stop Integrated Service. (PTSP). The Meureudu District Court has implemented this system.

The condition of one-stop integrated service (PTSP) The current court is still able to run well even though there is a shortage of personnel in the first service sector considering that those assigned to the main service are honorariums but the Meureudu district court tries to make the public no longer feel confused while in the court office because at the main door they have been welcomed / received and directed where and what is the purpose of their coming to the Court. One-stop integrated service (PTSP) The court still needs an arrangement / improvement in such a way, in order to provide even more optimal service, creating a comfortable, calm and cool atmosphere, both by court users and court officials themselves. All of this requires the attention of all components and the availability of an adequate budget allocation.

2. What are the obstacles in one door integrated service? Which was given by the Meureudu District Court?

1) In providing services, the Meureudu district court is still less professional and disciplined

2) There is still a lack of facilities and infrastructure to serve the community.

3) There is still a lack of staff in the main service sectors determined by the Meureudu District Court

\section{Conclusion}

In general, the Meureudu District Court has been able to meet its performance targets, although there are a number of things that need to be fixed first. The Meureudu District Court received the title $\mathrm{B}$ accredited within a year in providing services to the community. In providing services for the Meureudu district court, it has been right on target in allocating resources according to their capabilities

\section{References}

Adiwijaya, S., and Ningrum, P.A. (2019). Observing Palangkaraya Readiness as Indonesia's New Capital City from the Entrepreneurial Perspective. Budapest International Research and Critics Institute-Journal (BIRCI-Journal), P. 22-27.

Edy Sutrisno, 2014 Human Resource Management. Sixth issue. Jakarta Pranada Media Group.

Fred Luthans, 2016 Organizational Behavior. Tenth issue, Yogyakarta: PT. Andi

Gaol L, Jimmy, 2014 Human Resource Management. Jakarta: PT Grasindo

Hasibuan, Walayu 2012 human resource management. Jakarta: PT. Earth Literacy.

Kusumadewi, R.D., and Karyono, O. (2019). Impact of Service Quality and Service Innovations on Competitive Advantage in Retailing. Budapest International Research and Critics Institute-Journal (BIRCI-Journal), P. 366-374.

Moenir, 2002 Public Service Management in Indonesia. Earth Literacy: Jakarta

Moleong, Lexy, 2014 Qualitative Research Methods. Bandung: PT. Rosdakarya youth

Sugiyono, 2010 Qualitative and Quantitative Research Methods and R \& D. Bandung: Alfabeta.

Supranto, 2011 Measurement of Customer Satisfaction Levels. Rineka copyright: Jakarta 